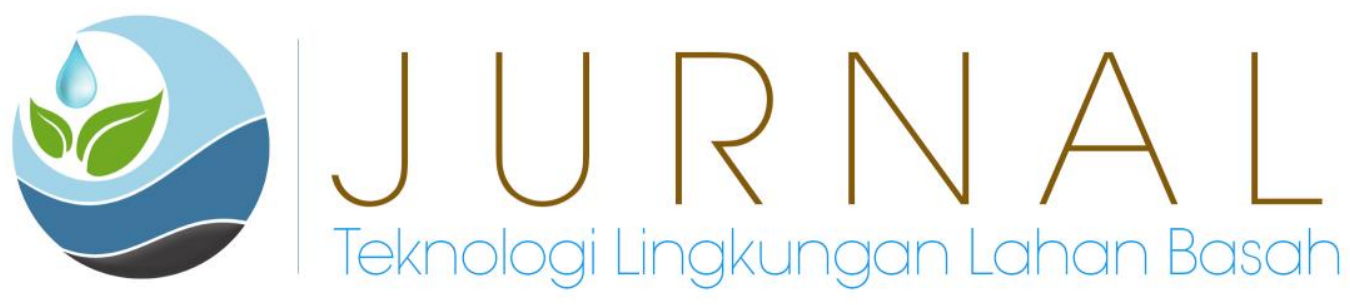

\title{
Pemanfaatan Arang Aktif Ampas Kopi sebagai Adsorben Kadmium pada Air Sumur
}

The Usage of Coffee Waste Actived Charcoal as Adsorbent of Cadmium in Well Water

\author{
Puput Baryatik $^{1}$, Anita Dewi Moelyaningrum ${ }^{1}$, Uswatun Asihta ${ }^{1}$, Wita Nurcahyaningsih ${ }^{1}$, \\ Azzumrotul Baroroh ${ }^{1}$, Herdian Riskianto ${ }^{1}$ \\ ${ }^{1}$ Bagian Kesehatan Lingkungan dan Kesehatan Keselamatan Kerja \\ Fakultas Kesehatan Masyarakat Universitas Jember \\ anitamoelyani@gmail.com
}

\begin{abstract}
Heavy metal cadmium (Cd) is still polluted the environment. It can be found in the wells around the landfill. This study aimed to analyze the active charcoal coffee ground to adsorb the cadmium in the water. This research method is the true experimental design with Completely Randomized Design. The first stage is making charcoal and then activated with $\mathrm{HCl}$. There are four groups $0 \mathrm{gram} / \mathrm{littre}(\mathrm{P} 0)$, perlakuan dengan $5 \mathrm{gram} /$ littre (P1), 8 gram/littre (P2) dan $10 \mathrm{gram} /$ littre (P3) with each group consisting of 6 replication. Treatement group contacted with active charcoal coffee around 2 hours. Results of research normality test later conducted ANOVA test. The test results informed that there is 0,000 difference significanly with $95 \%$ confidence intervals. The active charcoal coffee had significant to adsorb cadmium in the water.
\end{abstract}

Kata kunci : Coffee waste activated charcoal, cadmium, ground water

\begin{abstract}
Abstrak
Logam berat masih banyak ditemukan mencemari lingkungan. Cadmium (Cd) adalah logam berat yang bisa ditemukan di dalam air di sekitar tempat pembuangan sampah. Penelitian ini bertujuan untuk menganalisis arang aktif ampas kopi dalam menurunkan kadar $\mathrm{Cd}$ dalam air. Metode penelitian ini adalah true eksperimental dengan desain Rancangan Acak Lengkap. Tahap pertama adalah pembuatan arang kemudian diaktivasi dengan $\mathrm{HCl}$. Hasil uji kualitas arang aktif ampas kopi meliputi rendemen (98,5\%), kadar air (7\%), kadar abu (4\%) dan daya serap idoin $(687,96 \mathrm{mg} / \mathrm{g})$. Terdapat empat kelompok yaitu tanpa perlakuan $0 \mathrm{gr} / \mathrm{l}(\mathrm{P} 0)$, perlakuan dengan $5 \mathrm{gr} / \mathrm{l}(\mathrm{P} 1), 8 \mathrm{gr} / \mathrm{l}(\mathrm{P} 2)$ dan 10g/l (P3), di mana masing-masing kelompok terdiri dari 6 replikasi. Kelompok yang diberi perlakuan dikontakkan dengan arang aktif ampas kopi selama 2 jam. Selanjutnya dilakukan analisa kadar Cd dalam air dengan metode Spektrofotometri Serapan Atom. Hasil penelitian dilakukan uji normalitas kemudian dilakukan uji one way anova menggunakan SPSS. Hasil menunjukkan terdapat perbedaan secara signifikan sebesar 0,000 dengan interval kepercayaan 95\% antara kelompok kontrol dan perlakuan. Arang aktif ampas kopi secara signifikan dapat mengikat kadar kadmium dalam air.
\end{abstract}

Kata Kunci: Arang aktif ampas kopi, kadmium, air sumur 


\section{PENDAHULUAN}

Sistem pengelolaan sampah yang tidak tepat berpotensi mencemari air tanah karena sampah yang ditimbun akan membusuk bersama dengan air hujan yang akan menghasilkan air lindi. Lindi adalah bahan pencemar yang berpotensial mengganggu lingkungan dan kesehatan manusia. Air lindi mengandung bahan-bahan organik yang membusuk dan bahan-bahan logam berat (Himmah, Aminudi, dan Milala. 2009). ${ }^{5}$ Logam berat yang sering ditemukan dalam air lindi yaitu timbal $(\mathrm{Pb})$ (Widyasari $\mathrm{N}$, AD Moelyaningrum, RS Pujiati, ) ${ }^{22}$, kadmium (Cd) (Moelyaningrum AD dan RS pujiati) ${ }^{19}$, tembaga $(\mathrm{Cu})$ dan besi (Fe) (Maramis, Kristijanto, dan Notosoedarmo. 2006). ${ }^{11}$ Sampah yang menghasilkan limbah kadmium $(\mathrm{Cd})$ yaitu baterai, peralatan elektronik, keramik, tekstil, dan plastik (Himmah, Aminudi, dan Milala. 2009). ${ }^{5}$ Air lindi yang mengandung senyawa-senyawa organik dan anorganik dengan konsentrasi 5000 kali lebih tinggi dari pada air tanah, masuk dan mencemari air tanah atau air sungai (Maramis, A. 2008). ${ }^{12}$

Kualitas air bersih harus memenuhi persyaratan Permenkes RI nomor 416/MENKES/PER/IX/1990 tentang Syarat-Syarat dan Pengawasan Kualitas Air. Kualitas air sumur di sekitar tempat pembuangan sampah mengandung kadar logam berat Cd lebih besar dari baku mutu air bersih yang telah ditetapkan Permenkes RI nomor 416/MENKES/PER/IX/1990 yaitu sebesar 0,12 ppm (> BML 0,05 ppm) (Junita, L.N. 2013). ${ }^{8}$ Kadmium merupakan salah satu jenis logam berat yang berbahaya karena elemen ini beresiko tinggi terhadap pembuluh darah. Kadmium berpengaruh terhadap manusia dalam jangka waktu panjang dan dapat terakumulasi pada tubuh khususnya hati dan ginjal. Keracunan Cd kronis dapat menyebabkan gangguan kardiovaskular dan hipertensi (Sudarwin, 2008). ${ }^{17}$

Beberapa bahan organik terbukti mampu digunakan sebagai bahan adsorbent atau pengikat logam berat pada air seperti cangkang buah kakao (Moelyaningrum, AD, 2018), kulit durian (Zarkazi K, AD Moelyaningrum, PT Ningrum, 2018) ${ }^{23}$. Kabupaten Jember merupakan salah satu penghasil kopi terbesar di Jawa Timur. Selain itu banyak warga Jember mengkonsumsi kopi yang nantinya akan menghasilkan ampas kopi yang hanya dibuang begitu saja. Ampas kopi terbukti mampu mengikat logam berat timbal $(\mathrm{Pb})$ pada air (Moelyaningrum, AD et all, 2018). ${ }^{20}$

Ampas kopi termasuk bahan organik yang dapat dibuat menjadi arang aktif untuk digunakan sebagai adsorben atau bahan penyerap (Irmanto, 2009). ${ }^{7}$ Bahan baku yang berasal dari bahan organik dapat dibuat menjadi arang aktif karena mengandung karbon. Arang aktif adalah suatu padatan berpori yang dihasilkan dari bahan yang mengandung karbon dengan pemanasan pada suhu tinggi. Semakin luas permukaan arang aktif maka daya adsorpsinya semakin tinggi (Sembiring, M. T. dan T. S. Sinaga. 2003). ${ }^{16}$

Penelitian yang dilakukan Lubis dan Nasution (2002) ${ }^{10}$, mengatakan bahwa penggunaan arang aktif dari ampas kopi sebagai adsorben mampu mengadsorpsi ion besi pada air minum sampai dengan 99,34\% dan mampu mengadsorpsi logam merkuri sampai $99 \%$. Menurut Caetano $(2012)^{3}$ kandungan ampas kopi meliputi total karbon 47,8-58,9\%; total nitrogen 1,9-2,3\%; protein 6,7-13,6 g/100g; abu 0,43-1,6\%; selulosa 8,6\%. ${ }^{4}$ Oleh karena itu penelitian ini dilakukan dengan tujuan untuk memanfaatkan limbah ampas kopi untuk menurunkan kadar kadmium pada air sumur yang berada di sekitar TPA Pakusari dengan menggunakan arang aktif sampah kopi. 


\section{METODE PENELITIAN}

Bahan-bahan yang digunakan adalah bubuk kopi (jenis robusta), air sumur yang tercemar $\mathrm{Cd}$, aquades, $\mathrm{KI}, \mathrm{HCl} 0,1 \mathrm{M}$, larutan iod $0,1 \mathrm{~N}$, natrium thiosulfat $0,1 \mathrm{~N}$, indikator amilum 1\%. Alat-alat yang digunakan adalah alat-alat gelas laboratorium, muffle furnace, desikator, oven, ayakan mekanis 100 mesh, cawan porselin, alumunium foil, kertas saring, neraca analitik, botol Winkler, pH-meter, buret, statif dan software statistika SPSS.

Desain penelitian ini adalah True Eksperiment Design dengan bentuk Posttest-Only Control Designs dengan menggunakan Rancangan Acak Lengkap (RAL). Penelitian dilakukan menggunakan RAL non faktorial yang terdiri dari 4 perlakuan dengan 6 kali pengulangan untuk masing-masing perlakuan. Kelompok pertama adalah kelompok kontrol yaitu tanpa perlakuan(P0), kelompok kedua (P1) yaitu arang aktif ampas kopi sebanyak $5 \mathrm{gr} / 1,8 \mathrm{gr} / \mathrm{l}$ (P2), dan $10 \mathrm{gr} / \mathrm{l}$ (P3) selama 2 jam. Pengambilan sampel air sumur yang mengandung kadmium (Cd) dilakukan pada tanggal 12 Mei 2016. Pengujian kualitas arang aktif menggunakan perhitungan rendemen, penetapan kadar air, penetapan kadar abu, dan daya serap terhadap iodium. Teknik analisis data penelitian ini menggunakan analisis deskriptif dan analitik. Uji statistik dilakukan dengan menggunakan uji normalitas kemudian uji anova satu arah (one way anova). Selanjutnya dilakukan uji Cochran untuk melihat konsentrasi arang aktif ampas kopi yang paling efektif dalam menurunkan kadar kadmium dalam air.

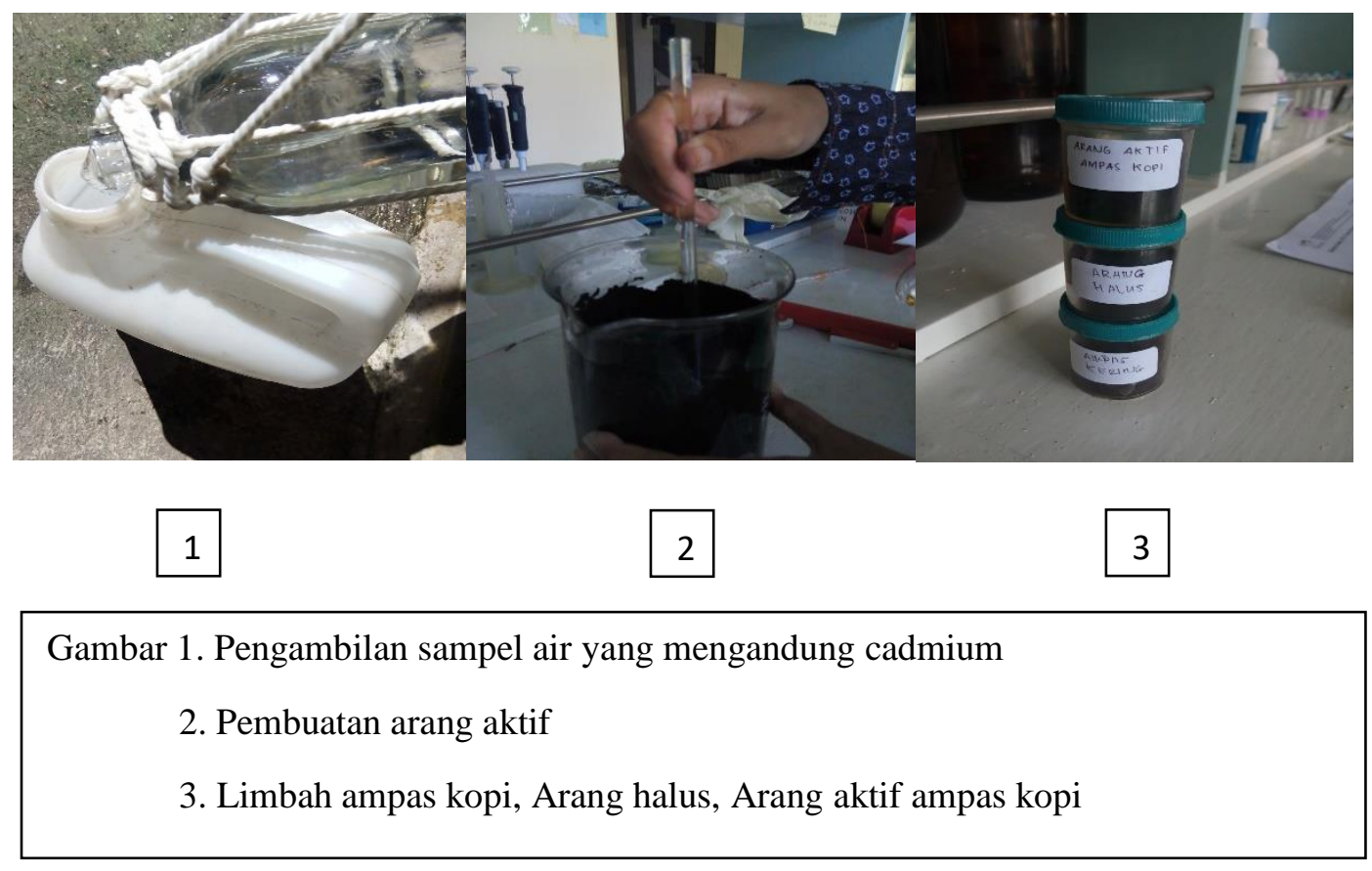

\section{HASIL}

Karakteristik arang aktif meliputi jumlah rendemen sebesar 98,5\%. Kadar air yang diperoleh dari hasil penelitian sebesar 7\% (memenuhi syarat) sehingga arang aktif dari ampas kopi dapat digunakan sebagai adsorben. Kadar abu yang diperoleh dari hasil penelitian sebesar 4\% (memenuhi standar mutu arang aktif). Daya serap arang aktif terhadap iodium yang dihasilkan pada penelitian ini sebesar 687,96 milligram/gram. Daya serap iodium arang aktif ampas kopi tidak memenuhi standar mutu arang aktif. Karakteristik arang aktif secara rinci dapat dilihat pada Tabel 1. 
Tabel 1. Hasil Kualitas Arang Aktif Ampas Kopi

\begin{tabular}{ccc}
\hline Parameter & $\begin{array}{c}\text { Standar Mutu SNI } \\
\text { No. 06-3730-1995 }\end{array}$ & $\begin{array}{c}\text { Hasil } \\
\text { Analisa }\end{array}$ \\
\hline Rendemen & - & $98,5 \%$ \\
Kadar air & Maksimum 15\% & $7 \%$ \\
Kadar abu & Maksimum 10\% & $4 \%$ \\
Daya serap iodin & Minimal 750 mg/g & $687,96 \mathrm{mg} / \mathrm{g}$ \\
\hline
\end{tabular}

Kadar Cd pada kontrol seluruh replikasi mayoritas lebih tinggi dari kelompok perlakuan, kecuali replikasi ke-6. Setiap replikasi pada perlakuan $\mathrm{X}_{1}, \mathrm{X}_{2}$, dan $\mathrm{X}_{3}$ hampir seluruhnya menunjukkan kadar $\mathrm{Cd}$ yang menurun seiring penambahan konsentrasi arang aktif, kecuali replikasi ke-4. Grafik Cd setiap kelompok secara rinci dapat dilihat pada Gambar 1 .

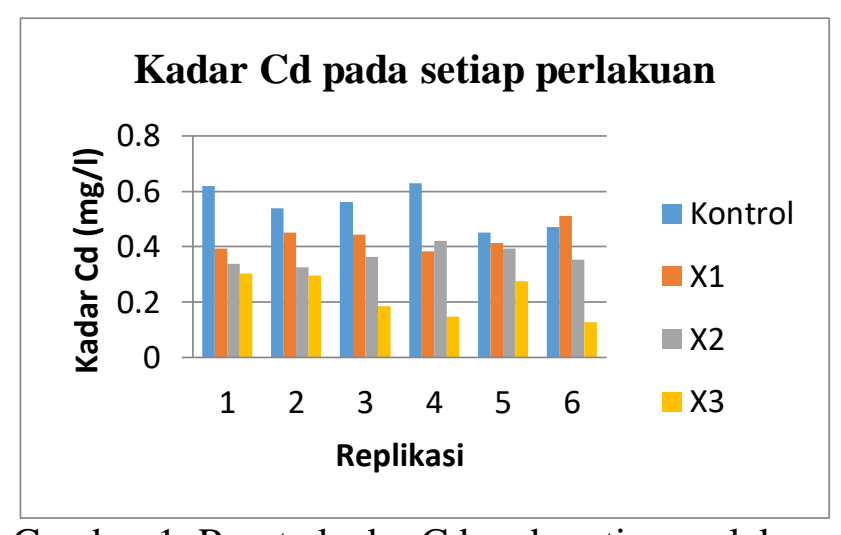

Gambar 1. Rerata kadar Cd pada setiap perlakuan

Hasil uji normalitas adalah $\mathrm{p}=0,200>0,05$ sehingga uji normalitas menunjukkan data berdistribusi normal. Untuk mengetahui perbedaan yang terjadi antar kelompok perlakuan maka dilakukan uji ANOVA. Nilai F hitung kadar Cd dalam air sumur setelah mengalami perlakuan sebesar 0,000 (lebih kecil dari 0,05) Artinya, seluruh kelompok perlakuan memiliki rata-rata populasi yang berbeda, baik pada kelompok control (P0), kelompok (P2), X (P3), dan X(P4).

Kelompok kontrol berbeda secara signifikan dengan kelompok perlakuan (P1, P2, P3) dengan nilai signifikansi masing-masing 0,021; 0,000; dan 0,000. Kelompok P1 berbeda signifikan dengan kelompok kontrol dan P3, dengan nilai signifikansi $(0,021)$ dan $(0,000)$. Kelompok P2 berbeda signifikan dengan kelompok kontrol dan P3, dengan nilai signifikansi $(0,000)$ dan $(0,003)$. Kelompok P3 berbeda signifikan dengan kelompok kontrol P1, dan P2, dengan nilai signifikansi $(0,000 ; 0,000$; dan 0,003). Hasil uji One Way Anova secara rinci dapat dilihat pada Tabel 2. 
Tabel 2. Hasil Uji One Way Anova

\begin{tabular}{|c|c|c|c|c|}
\hline Perlakuan & Perlakuan(J) & $\begin{array}{c}\text { Mean } \\
\text { Difference (I-J) }\end{array}$ & Std error & Sig \\
\hline \multirow{2}{*}{ Kontrol } & $\mathrm{X} 1$ & $.1130667^{\star}$ & .0353241 & .021 \\
\cline { 2 - 5 } & $\mathrm{X} 2$ & $.1794500^{\star}$ & .0353241 & .000 \\
\cline { 2 - 5 } & $\mathrm{X} 3$ & $.3230167^{\star}$ & .0353241 & .000 \\
\hline \multirow{2}{*}{$\mathrm{X} 1$} & $\mathrm{X} 2$ & .0663833 & .0353241 & .268 \\
\cline { 2 - 5 } & $\mathrm{X} 3$ & $.2099500^{\star}$ & .0353241 & .000 \\
\hline $\mathrm{X} 2$ & $\mathrm{X} 3$ & $.1435667^{\star}$ & .0353241 & .003 \\
\hline
\end{tabular}

* The mean difference is significant at the .05 level

Persentase penurunan Cd pada penelitian ini adalah pada kelompok P1 sebesar 20,74\%, kelompok P2 sebesar 31,40\%, dan kelompok P3 sebesar 55.75\%. Hasil persentase penurunan kadar Cd secara rinci dapat dilihat pada Tabel 3.

Tabel 3. Rerata Hasil Penurunan Kadar Cd dalam Air Sumur

\begin{tabular}{|c|c|c|c|}
\hline Perlakuan & $\begin{array}{c}\text { Rerata Kadar } \\
\text { Cd (mg/l) }\end{array}$ & $\begin{array}{c}\text { Penurunan Kadar } \\
\text { Cd (mg/l) }\end{array}$ & $\begin{array}{c}\text { Persentase } \\
\text { penurunan Cd (\%) }\end{array}$ \\
\hline Kontrol & 0.545 & - & - \\
\hline X1 & 0.432 & 0.113 & 20.74 \\
\hline X2 & 0.374 & 0.171 & 31.40 \\
\hline X3 & 0.241 & 0.304 & 55.75 \\
\hline
\end{tabular}

\section{PEMBAHASAN}

Menurut Caetano (2012) menyatakan bahwa komponen utama dalam ampas kopi adalah karbon yaitu sebesar 47,8-58,9\%. Caetano, N. 2012. ${ }^{3}$ Karbon yang terkandung dalam ampas kopi berperan untuk pengikatan ion logam pada proses adsorpsi. Bahan baku yang berasal dari hewan, tumbuh-tumbuhan, limbah ataupun mineral yang mengandung karbon dapat dibuat menjadi arang aktif (Sembiring, M. T. dan T. S. Sinaga. 2003). ${ }^{16}$

Pada penelitian ini dilakukan proses aktivasi arang ampas kopi untuk memperbesar ukuran pori-pori dari arang agar kemampuan penyerapannya terhadap logam Cd menjadi semakin banyak. Hal ini sesuai dengan penelitian yang dilakukan oleh Widayanti dkk. $(2012)^{18}$, menyebutkan bahwa arang yang telah diaktivasi tingkat penyerapannya lebih tinggi dibandingkan dengan tanpa aktivasi. Proses aktivasi ini akan menyebabkan zat pengotor yang menyumbat pori-pori karbon hilang, sehingga jumlah pori-pori karbon aktif semakin besar dan daya adsorpsinya terhadap cairan atau gas akan semakin tinggi (Widayanti, Ishak, I. dan Aman, L.O. 2012). ${ }^{18}$

Penetapan rendemen arang aktif bertujuan untuk mengetahui jumlah arang aktif yang dihasilkan setelah melalui proses karbonasi (Pujiarti. R dan J. P. Gentur Sutapa. 2005). ${ }^{14}$ Penetapan jumlah rendemen tidak ditetapkan dalam SNI. Penetapan kadar air bertujuan untuk mengetahui sifat higroskopis arang aktif. Semakin rendah kadar air maka semakin banyak tempat dalam pori yang dapat ditempati oleh adsorbat sehingga adsorpsi 
berlangsung secara optimal (Mu'jizah, S., 2010). ${ }^{13}$ Penentuan kadar abu bertujuan untuk mengetahui kandungan sisa mineral dalam arang aktif yang tidak terbuang saat karbonisasi dan aktivasi. Mineral yang masih tersisa akan menyebabkan terjadinya penyumbatan pori-pori arang aktif sehingga mempengaruhi adsorpsi yang terjadi (Herlandien, Y. L. 2013). ${ }^{4}$

Uji iod merupakan parameter untuk mengetahui kemampuan arang aktif dalam menyerap molekul-molekul dengan berat molekul kecil dan zat dalam fasa cair. Semakin tinggi angka iod maka semakin baik arang aktif dalam menyerap molekul yang kecil atau zat dalam fasa cair (Idrus, 2013). ${ }^{6}$ Bentuk arang aktif ampas kopi yang digunakan sebagai adsorben dalam penelitian ini adalah dalam bentuk serbuk. Suatu zat padat akan lebih cepat bereaksi jika permukaannya diperluas dengan cara mengubah bentuk kepingan menjadi serbuk atau ukuran diperkecil, sehingga luas permukaan bidang tumbukan antara zat pereaksi akan semakin besar. Semakin luas permukaaan arang aktif maka daya adsorpsinya semakin tinggi (Sembiring, M. T. dan T. S. Sinaga. 2003). ${ }^{16}$

Faktor lain yang dapat mempengaruhi adsorpsi adalah konsentrasi adsorben. (Arivoli, S., Thenkuzhalia, M., dan Prasath, P. M. D. 2009). ${ }^{1}$ Konsentrasi adsorben merupakan parameter yang penting karena dapat menentukan kapasitas adsorben optimum dalam proses mengadsorpsi adsorbat. Pada penelitian ini konsentrasi optimum dalam mengadsorpi logam $\mathrm{Cd}$ yaitu pada konsentrasi 10 gram. Hal ini dikarenakan dengan meningkatnya dosis adsorben maka luas permukaan untuk mengadsorpsi juga semkain meningkat. Sehingga arang aktif ampas kopi lebih mudah mengikat ion logam Cd dalam air sumur. Dapat disimpulkan bahwa semakin meningkatnya konsentrasi, maka interaksi antara adsorben dengan adsorbat semakin besar sehingga adsorpsi cenderung meningkat (Azouaou, et al. 2010). ${ }^{2}$

Selain itu lama waktu kontak dapat mempengaruhi adsorpsi, yaitu semakin lama waktu adsorpsi maka frekuensi tumbukan antara adsorben dengan partikel adsorbat semakin besar pula. Hasil penelitian menyebutkan bahwa persentase penurunan kadar $\mathrm{Cd}$ tertinggi yaitu pada kelompok P3.

Pengurangan atau penurunan kadar $\mathrm{Cd}$ dalam air sumur perlu dilakukan seminimal mungkin karena logam $\mathrm{Cd}$ sangat berbahya bagi makhluk hidup dan lingkungan. Kadmium (Cd) merupakan logam berat non esensial dengan potensi toksisitas yang tinggi. Keracunan $\mathrm{Cd}$ kronis dapat menyebabkan gangguan kardiovaskular, aterosklerosis, diabetes, nefropati dan hipertensi. ${ }^{12}$ Toksisitas kronis $\mathrm{Cd}$, baik melalui inhalasi maupun oral, bisa menyebabkan kerusakan tubulus renalis, kerusakan ginjal yang yang ditunjukkan oleh ekskresi berlebihan, protein berat molekul rendah, gagal ginjal, gangguan sistem kardiovaskuler, gangguan sistem skeletal, menurunkan fungsi pulmo, empisema, kehilangan mineral reabsorpsi $\mathrm{Ca}$, dan terjadinya peningkatan ekskresi $\mathrm{Ca}$ yang berpengaruh terhadap tulang. Peningkatan ekskresi $\mathrm{Ca}$ tersebut diantaranya menyebabkan osteoporosis dan osteomalasia, anemia, diskolorasi gigi menjadi kuning, rhinitis, ulserasi septum nasal, anosmia, proteinuria, azotemia, jaundice, terjadinya kanker paru-paru dan prostat. $^{26}$

Hasil penelitian menyebutkan bahwa seluruh kelompok perlakuan memiliki rata-rata populasi yang berbeda, baik pada kelompok kontrol, kelompok P1,P2,P3. Adsorpsi yang terjadi pada arang aktif dengan logam Cd dalam air sumur merupakan adsorpsi fisik. Peristiwa adsorpsi pada arang aktif terjadi karena adanya gaya Van der Walls yaitu gaya tarik-menarik intermolekuler antara molekul padatan dengan solut yang diadsorpsi lebih besar daripada gaya tarik-menarik sesama solut itu sendiri di dalam larutan, maka solut 
akan terkonsentrasi pada permukaan padatan (Rizki, 2015). ${ }^{15}$ Peristiwa adsorpsi terjadi karena permukaan adsorben mengalami ketidakseimbangan gaya, akibatnya permukaan adsorben tersebut mudah menarik zat lain, sehingga kesetimbangan gaya tercapai. Daya adsorpsi arang aktif terjadi karena arang mempunyai pori-pori dalam jumlah besar yang dapat mengadsorpsi adsorbat (Azouaou, et al. 2010). ${ }^{2}$

\section{PENUTUP}

Penelitian ini menyimpulkan bahwa seluruh kelompok perlakuan memiliki rata-rata populasi yang berbeda, baik pada kelompok kontrol, kelompok P1, P2, dan P3. Hasil signifikansi yang diperoleh dari perhitungan sebesar 0,000 . Penurunan kadar $\mathrm{Cd}$ tertinggi yaitu pada kelompok P3 sebesar 55.75\%.

Saran yang dapat diberikan yaitu arang aktif dari limbah ampas kopi dapat digunakan untuk menurunkan kadar cadmium dalam air. Selain itu, bagi peneliti selanjutnya dapat melakukan pengontrolan $\mathrm{pH}$, temperatur, kecepatan pengadukan pada saat pengontakkan dengan arang aktif ampas kopi .

\section{UCAPAN TERIMA KASIH}

Penelitian ini dibiayai oleh Kementrian Riset, Teknologi dan Pendidikan Tinggi Kementrian Riset dan Teknologi melalui Dana hibah Program Kreativitas Mahasiswa (PKM Penelitian) tahun 2016.

\section{DAFTAR PUSTAKA}

1 Arivoli, S., Thenkuzhalia, M., dan Prasath, P. M. D. 2009. Adsorption of Rhodamin $B$ by Acid Activated Carbon-Kinetic, Thermodynamic and Equalibrium Studies, Jurnal Orbital. Vol. 1 (2): 138-155

http://www.orbital.ufms.br/index.php/Chemistry/article/viewFile/24/13 Diakses pada 10 Mei 2016

2 Azouaou, et al. 2010. Adsorption of Cadmium from Aqueous Solution onto Untread Coffee Ground: Equilibrium, Kinetics and Thermdynamics. Journal of Hazardous Materials. http://www.aidic.it/cet/14/38/026.pdf. Diakses pada 15 Mei 2016

3 Caetano, N. 2012. "Valorization of Coffee Grounds for Biodiesel Production". Chemical Engineering Transactions, Vol. 26, 2012. http://www.aidic.it/cet/12/26/045.pdf. Diakses pada 26 April 2016

4 Herlandien, Y. L. 2013. Pemanfaatan Arang Aktif sebagai Adsorban Logam Berat dalam Air Lindi di TPA Pakusari Jember. Skripsi. Fakultas Matematika dan Ilmu Pengetahuan Alam, Universitas Jember.

5 Himmah, Aminudi, dan Milala. 2009. Potensi Limbah Air Lindi oleh Pseudomonas fluoresens sebagai Prebiotik Tanaman. Tidak dipublikasikan. Program Kreativitas Mahasiswa. Bogor: Institut Pertanian Bogor.

6 Idrus, R., Lapanporo, B, P., Putra, Y, S, 2013, Pengaruh Suhu Aktifasi Terhadap Kualitas Karbon Aktif BErbahan Dasar Tempurung Kelapa, Prisma Fisika, Volume 1, Nomor 1, Halaman 50-51.

7 Irmanto, Suyata."Penurunan Kadar Amonia, Nitrit dan Nitrat Limbah Cair Industri Tahu Menggunakan Arang Aktif dari Ampas Kopi”.Molekul. 4 No. 2(2009): 105-114 http://journal.uin-alauddin.ac.id

8 Junita, L.N. 2013. Profil Penyebaran Logam Berat di Sekitar TPA Pakusari Jember. Skripsi. Program Sarjana Universitas Jember, Jember. 
9 Kukongviriyapan, U., Apaijit, K., Kukongviriyapan, V. 2016. Oxidative Stress and Cardiovascular Dysfunction Associated with Cadmium Exposure: Beneficial Effects of Curcumin and Tetrahydrocurcumin. Tohoku, 239(1):25-38 http://www.ncbi.nlm.nih.gov/pubmed/27151191 Diakses pada 2 Juni 2016

10 Lubis, S. dan R. Nasution. 2002. Pemanfaatan Limbah Bubuk Kopi sebagai Adsorben pada Penurunan Kadar Besi (Fe anorganik) dalam Air Minum. Jurnal Natural, $\begin{array}{lllll}\text { Volume } & 2, & \text { No. 2002:12-16. }\end{array}$ http://elib.pdii.lipi.go.id/katalog/index.php/searchkatalog/byId/40005 Diakses pada 13 Mei 2016

11 Maramis, Kristijanto, dan Notosoedarmo. 2006. Sebaran Logam Berat dan Hubungannya dengan Faktor Fisiko-Kimiawi di Sungai Kreo, Dekat Buangan Air Lindi TPA Jatibarang, Kota Semarang. Jurnal Akta Kimindo, 1 (2): 93-97.

12 Maramis, A. 2008. Pengelolaan Sampah dan Turunannya di TPA. Alumni Program Pasca Sarjana Magister Biologi Terapan.Salatiga: Universitas Satyawacana.

13 Mu'jizah, S., 2010. Pembuatan dan Karakterisasi karbon Aktif dari Biji Kelor (Moringa oleifera. Lamk) dengan $\mathrm{NaCl}$ sebagai Bahan Pengaktif. Skripsi. Fakultas Sains dan Teknologi, Universitas Islam Negeri Maulana Malik Ibrahim Malang.

14 Pujiarti. R dan J. P. Gentur Sutapa. 2005. Mutu Arang Aktif dari Limbah Kayu Mahoni (Switenia macrophylla King). Jurnal Ilmu dan Teknologi Kayu tropis Vol 3. No. 2. Yogyakarta: Universitas Gadjah Mada. http://teknologihutan.fkt.ugm.ac.id/userfiles/download/Mutu_Arang_Aktif_dari_Li mbah_Kayu_Mahoni_sebagai_Bahan_Penjernih_Air___Rini_Pujiarti.pdf. Diakses pada 29 April 2016

15 Rizki, Adi Prima. 2015. Isoterm Langmuir, Model Kinetika dan Penentuan Laju Reaksi Adsorpsi Besi Dengan Arang Aktif Dari Ampas Kopi. Jurusan Teknik Kimia, Fakultas Teknik - Universitas Mulawarman.

16 Sembiring, M. T. dan T. S. Sinaga. 2003. Arang Aktif (Pengenalan dan Proses Pembuatannya). http://library.usu.ac.id/download/ft/industri-meilita.pdf. Diakses Tanggal 2 September 2015.

17 Sudarwin. 2008. "Analisa Spasial Pencemaran Logam Berat Pb dan Cd Pada Sedimen Aliran Sungai dari TPA Jatibarang Semaarng", Thesis pada Program Magister Kesehatan Lingkungan Universitas Diponegoro.

18 Widayanti, Ishak, I. dan Aman, L.O. 2012. Studi Daya Aktivasi Arang Sekam Padi pada Proses Adsorpsi Logam Cd. Gorontalo: Jurusan Kimia FMIPA. UNG. http://repository.ung.ac.id/get/simlit_res/1/104/Studi_Daya_Aktivitas_Arang_Seka m_Padi_Pada_Proses_Adsorpsi_Logam_CD.pdf. Diakses pada 29 April 2016

19 Moelyaningrum AD, dan RS. Pujiati, 2015. Cadmium (Cd) and Mercury (Hg) in the Soil, Leachate and Ground Water at the final Waste Disposal Pakusari Jember Distric Area. International Journal of Sciences: Basic and Applied Research (IJSBAR), Vol 24, No.2.

http://gssrr.org/index.php?journal=JournalOfBasicAndApplied\&page=article\&op= view\&path $\% 5 \mathrm{~B} \% 5 \mathrm{D}=4541$.

20 Moelyaningrum AD, 2015. The Potential of Cacao Pod Rind Waste (Theobroma cacao) to Adsorb Heavy Metal ( $\mathrm{Pb}$ and $\mathrm{Cd}$ ) in Water. Book chapter. Sustainable Future for Human Security, 265-276. https://link.springer.com/book/10.1007/978981-10-5433-4

21 Moelyaningrum AD, 2018 The Robusta Coffee Grounds Residues to Adsorb the Heavy Metal Lead (Pb) in the Water. Journal of Physics: Conference Series $1114 \mathrm{p}$. 12058. http://iopscience.iop.org/article/10.1088/1742-6596/1114/1/012058/meta 
22 Widyasari N, AD Moelyaningrum, RS Pujiati, 2013. Analisis potensi pencemaran timbal $(\mathrm{Pb})$ pada tanah, air lindi dan air tanah (sumur monitoring di Tempat Pembuangan Akhir Pakusari Kabupaten Jember. http://repository.unej.ac.id/handle/123456789/59247

23 Zarkasi K, AD Moelyaningrum, PT Ningrum, 2018. Penggunaan arang aktif kulit durian (Durio zibenthinus Murr) terhadap tingkat adsorpsi kromium pada limbah batik. Jurnal efektor. Vol 5 (2) p.67-73. http://ojs.unpkediri.ac.id/index.php/efektore/article/view/12069 